at a provincial hospital. I have read the remarks, which are exceedingly succinct and concise, with great care, and personally I think your readers are under an obligation to the writer for the shrewd and experienced suggestions which are made. My thought on considering the subject-matter was that under the extreme and asthenic general condition of the little patient would not local anresthesia for the performance of the abdominal operation have been more applicable than chloroform inhalation? I can, and so I know can many other surgeons, speak of the value and the perfect security of performing abdominal sections in patients after the previous employment in the area of the proposed operation of the hypodermic administration of eucaine. Without referring to a number of cases in which minor operations have been successfully and painlessly performed after the injection of the above-mentioned drug, I may further say that I have, without the slightest knowledge or exhibition of feeling on the part of the patient (as stated when questioned afterwards), performed the following abdominal operations : suprapubic cystotomy, an oöphorectomy, and within the last six weeks I have cut down upon the liver, explored it, and finally incised a large abscess, and clearing out the cavity concluded the operation, the patient (a young man) returning to his bed very little the worse for the procedure. I am, Sirs, yours faithfully,

Wolverhampton, Jan. 21st, 1901.

T. VINCENT JACKSON,

\section{THE EFFICIENCY OF LIQUID EXTRACT OF ERGOT.}

\section{To the Editors of THE LANCET.}

Sins,-In Professor Attfield's " Digest of Researches and Oriticisms" on the British Pharmacopoia, prepared for the General Medical Council, he remarks that it is a matter of importance to collect opinions from practitioners as to whether or not the liquid extract of ergot is as trustworthy as the extract (ergotine); and if it is not to remodel the process for its preparation on that of the apparently satisfactory extract. Now ergotine is obtained by extracting ergot with alcohol, whilst the fluid extract is prepared by treating it with cold water. The universal experience of practitioners is, I think, that the latter is most uncertain in its effects and always liable to disappoint. It is also, as I can testify, of very variable strength and prone to decomposition. On the contrary, the solid extract popularly called ergotine is a most efficient diug and may be relied on to act almost with mathernatical certainty.

Dublin, Jan. 19th, 1901. I am, Sirs, yours faithfully, J. C. MCW ALTER.

\section{"ISOLATION HOSPITALS." \\ To the Editors of THE LANCET.}

SIRs,-In reply to Mr. E. D. Agnew's letter on this subject in THE LANCET of Jan. 19th, p. 214, I beg to state emphatically that the second outbreak of scarlet fever did not occur till six days after the convalescents had returned home from the isolation hospital. The parents in each case are willing to testify to this, and to use the words of one of the mothers, "their skins were as clear as marble and their health perfect." The boy Neville returned from the hospital with an inflammatory discharge from the nose which was so severe that I have kept all the children of the house away from school-this is not yet quite well; and the desquamation suggested by Mr. Agnew in the case of the child Foster is some congenital cuticular shedding which she was suffering from when attacked and which I have of ten treated her for. There is not the slightest possible doubt that the second outbreak of scarlet fever was due to infection brought by the "return" cases from the Bishop's Stortford Isolation Hospital. I am, Sirs, yours faithfully,

Stansted, Essex, Jan. 22nd, 1901. Edgar Pittway.

\section{OBTUSENESS OR ANIMUS?}

\section{To the Editors of THE LANCET.}

SIRs, - In the review of my "Text-book of Pathology in Relation to Mental Diseases" in THE LANCET of Jan. 5th there is a statement so misleading and so damaging that $I$ must request you to allow me to make an explanation regarding it. Fair criticism should always be welcome to an author, for he can invariably profit by it ; unfair criticism, whether attributable to the obtuseness or to the animus of the reviewer, is for many reasons generally best left alone; but gross misrepresentation of facts, involving a serious reflection upon the author, can hardly be allowed to pass unchallenged.

The statement to which I refer is the following: "Many of the illustrations are taken from the standard works, such as those of Golgi, Lugaro, and others." Now, in the common acceptation of the term, a "standard work" is a book, and in this sense the writer of the review himself uses the word "work" in the two immediately succeeding sentences as well as in the first line of his critique. The information that your readers must therefore inevitably gather from the sentence I have quoted, taken in the context in which it stands, is that, in order to illustrate this textbook, I have been obliged to make free use of illustrations contained in already existing text-books. I have done nothing of the kind; the imputation is wholly false. The facts are that the "many illustrations" referred to by your reviewer comprise 14 figures out of 182 contained in $\mathrm{my}$ book, and that these 14 figures are taken, not from already existing text-books, but from recent papers in Italian neurological journals, and serve to illustrate that portion of the chapter upon the nerve-cells which purports to be nothing more than a critical digest of recent researches upon the normal and pathological histology of these tissueelements. It is worthy of note that the "others" in the sentence quoted consist of two individuals.

I am, Sirs, yours faithfully,

Hill-square, Edinburgh, Jan. 14th, 1901.

W. FORD ROBERTSON.

*** We regret that the reviewer should have failed to make clear how many illustrations in Dr. W. Ford Robertson's book were not oliginal and what was their exact source. We wonder that Dr. Robertson did not hesitate before charging the writer of a favourable review with obtuseness or animus.-ED. $\mathrm{L}$.

\section{ROBERT LOUIS STEVENSON : "FEVER" AND MOSQUITOES.}

\section{To the Editors of THM LANOWT.}

Sins,-It is interesting to note that in 1888 Robert Louis Stevenson wrote of Atuona in "The Marquesas" as follows: "In Atuona, a village planted in a shore-side marsh, the houses standing everywhere intermingled with the pools of a taro-garden, we find every condition of tropical danger and discomfort; and yet there are not even mosquitoes-not even the hateful day-fly of Nuka-hiva-and fever and its concomitant, the island fe'efe'e, are unknown." Stevenson merely records the facts; but in these days this note, made by an accurate observer, of a spot where the absence of mosquitoes coincided with the absence of fever and of elephantiasis is worthy of remark.

I am, Sirs, yours faithfully,

Leeds, Jan. 18th, 1901. H. D. O'NEILL.

\section{$=$}

\section{MANCHESTER.}

(From OUR OWN CORRESPONDENT.)

\section{The Beer Inquiry.}

THE inquiry before the Manchester city coroner regarding the death of one of the sufferers from arsenical poisoning is concluded. The jury returned an open verdict, to which a rider was added that a vote of censure should be passed on Messrs. Groves and Whitnall, Limited, the brewers, Messrs. J. Nicholson and Sons, Limited, the sulphuric acid manufacturers, Dr. Morris, the consulting chemist, and Mr. Cook, works chemist to Messrs. Bostock, for carelessness. This, as the coroner said, is practically a verdict that death was due to poisoning by arsenic. He said, moreover, that he did not embody the censure in the verdict because it was a rider. He agreed with a remark of Mr. Fletcher Moulton that there was no evidence of carelessness on the part of the brewers. In his address to the jury the coroner said that the thanks of the whole community were due to Dr. E. S. Reynolds for the part he had taken in the case. He also 